Kalanchoe hypseloleuce (Crassulaceae), a new species from eastern Ethiopia, with notes on its habitat

Friis, Ib; Gilbert, Michael G.; van Breugel, Paulo; Weber, Odile; Demissew, Sebsebe

Published in:

Kew Bulletin

DOI:

10.1007/S12225-017-9704-7

Publication date:

2017

Document version

Peer reviewed version

Citation for published version (APA):

Friis, I., Gilbert, M. G., van Breugel, P., Weber, O., \& Demissew, S. (2017). Kalanchoe hypseloleuce (Crassulaceae), a new species from eastern Ethiopia, with notes on its habitat. Kew Bulletin, 72, [30]. https://doi.org/10.1007/S12225-017-9704-7 


\section{Kew Bulletin}

\section{Kalanchoe hypseloleuce (Crassulaceae), a new species from eastern Ethiopia, with notes on its habitat \\ --Manuscript Draft--}

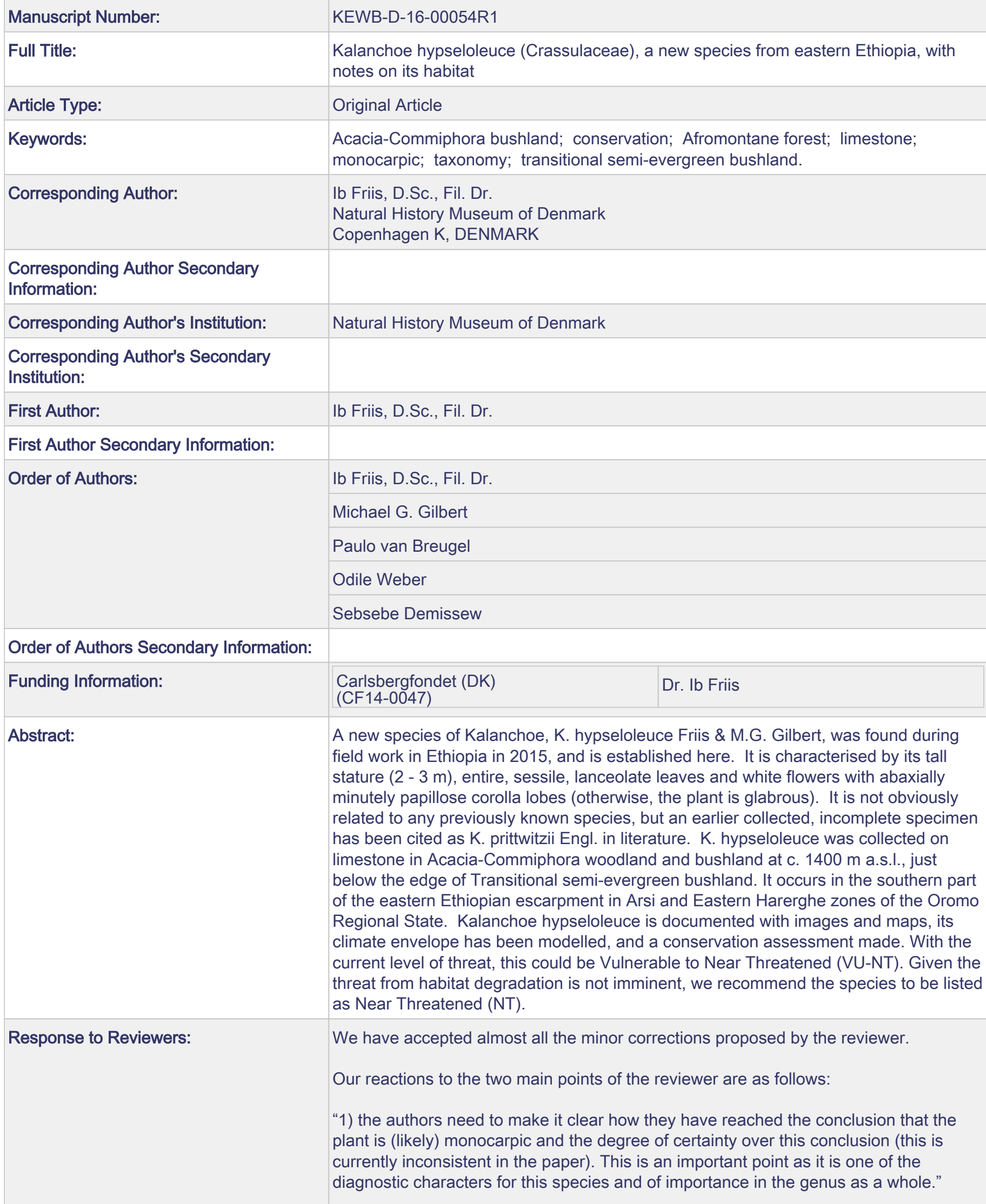


It is not an essential diagnostic character that the plant is monocarpic. The species can be recognised also without this character. We have changed the key and deleted any reference to the life cycle of the plant in the Description and 'Recognition'. In the 'Conservation Status' we have said: "We assume that the plant is monocarpic (see discussion in 'Notes')." We have inserted text in the 'Notes' to make it clear how we have reached the conclusion that the plant is (presumably) monocarpic.

"2) the conservation assessment needs some reworking. The conclusion of LC is okay, although I think there is some merit in suggesting an alternative of VU B1ab(iii). More importantly, the discussion on range (EOO and $\mathrm{AOO}$ ) size and its implication for a criterion B assessment needs rewording - a GeoCAT calculation does NOT give a conservation assessment; it merely indicates whether the $\mathrm{EOO}$ and $\mathrm{AOO}$ calculations fall within the B1 and B2 range thresholds for the three threat categories."

We have changed our statement about the GeoCAT calculations to mentioning that the EOOs and AOOs fall within B1 and B2 range thresholds for Vulnerable (VU) and Endangered $(E N)$ and have rewritten the entire conservation assessment to Vulnerable to Near Threatened (VU - NT). Although the EOOs and AOOs fall within B1 and B2 range thresholds for Vulnerable (VU) and Endangered (EN) we suggest a conservation assessment of Near Threatened (NT), because there is currently no imminent threat to the plant in part of its distribution area. 


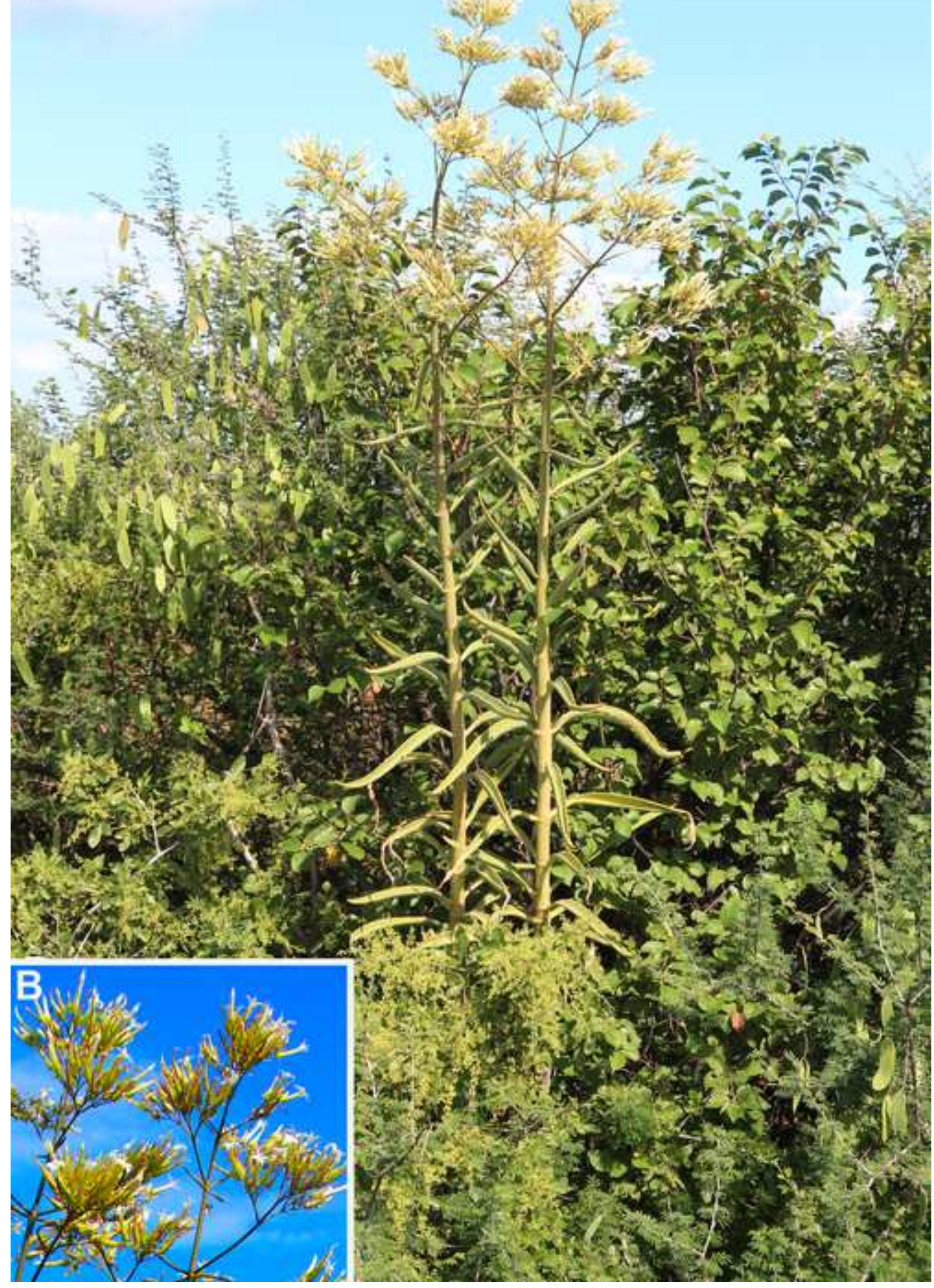



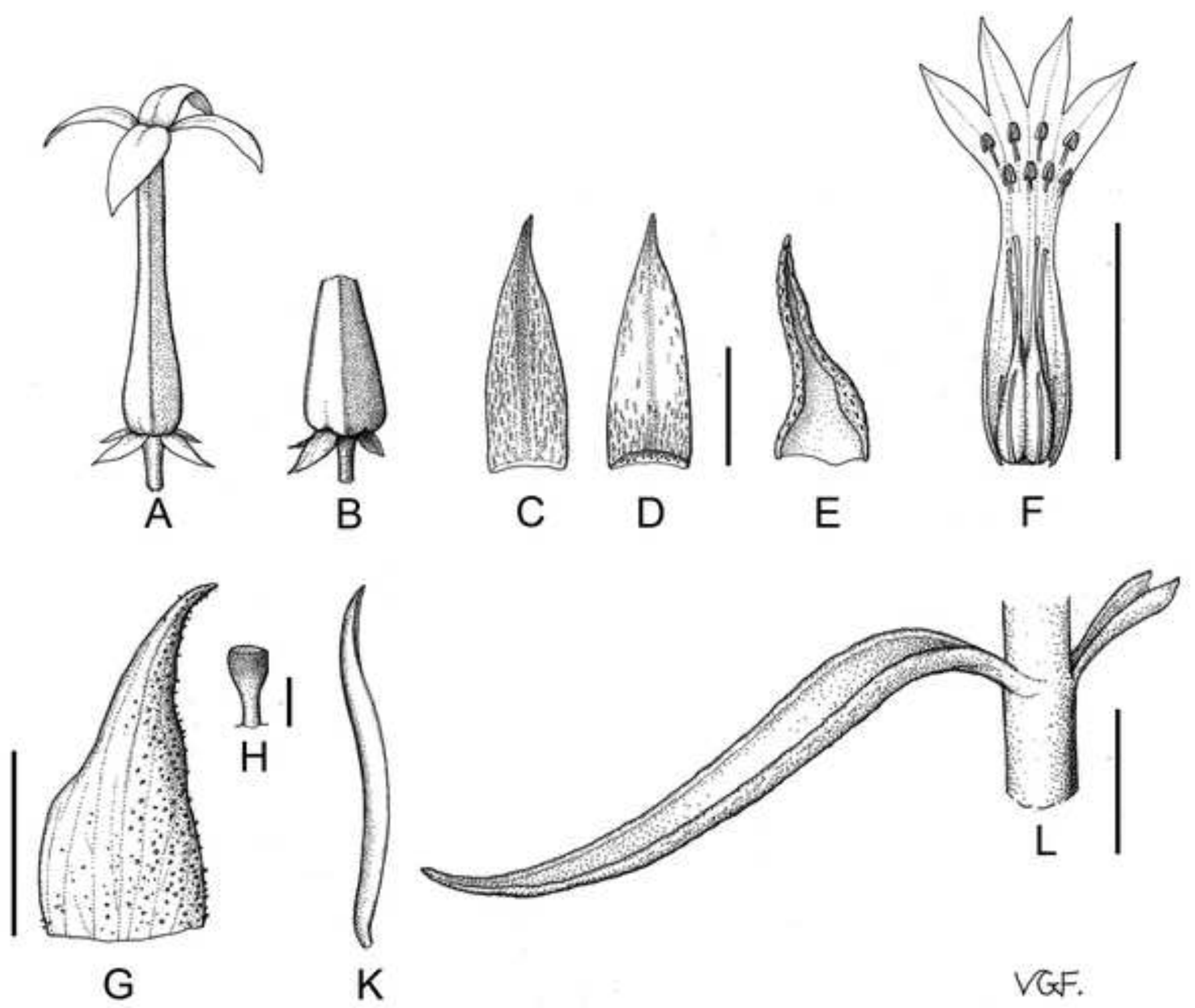


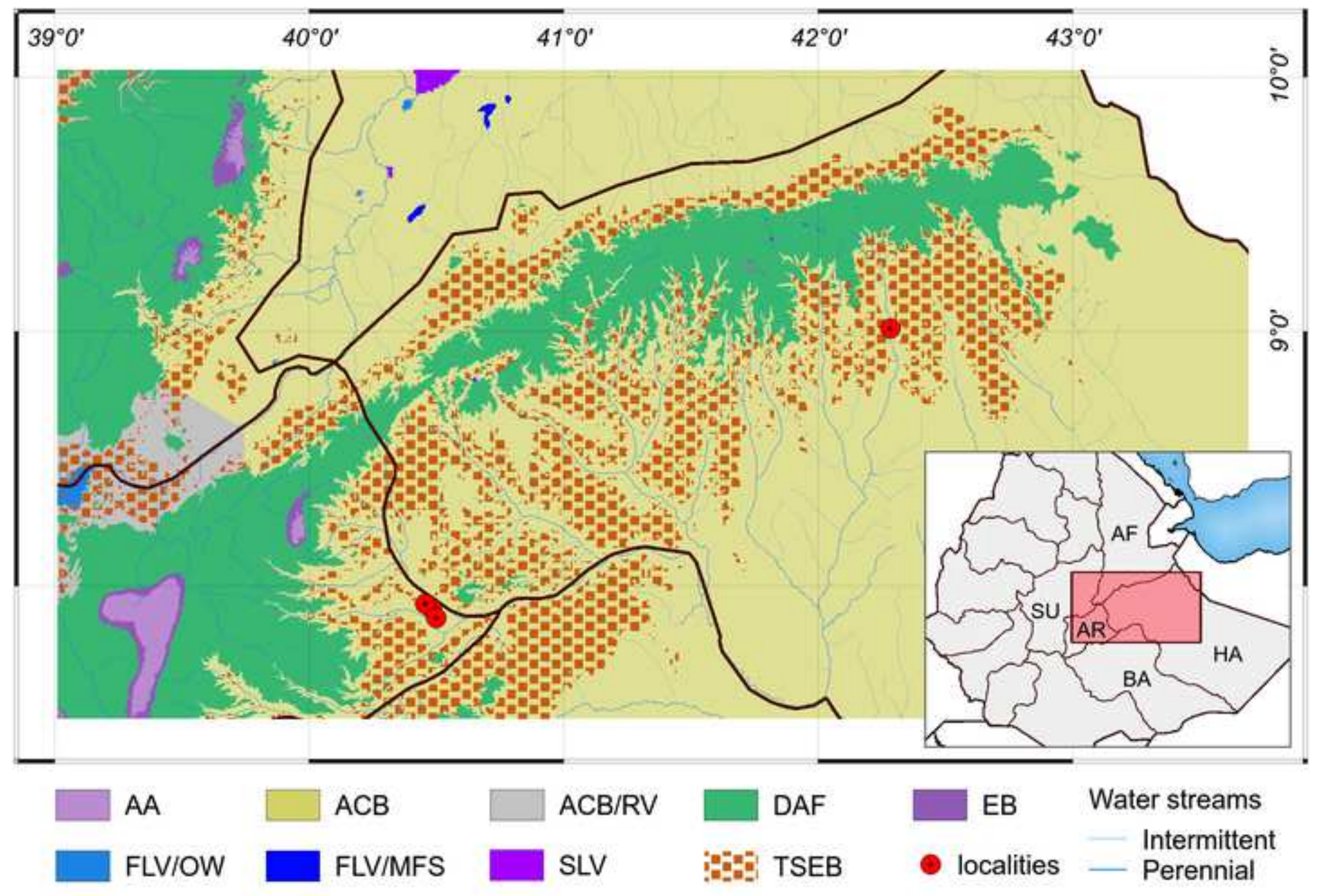




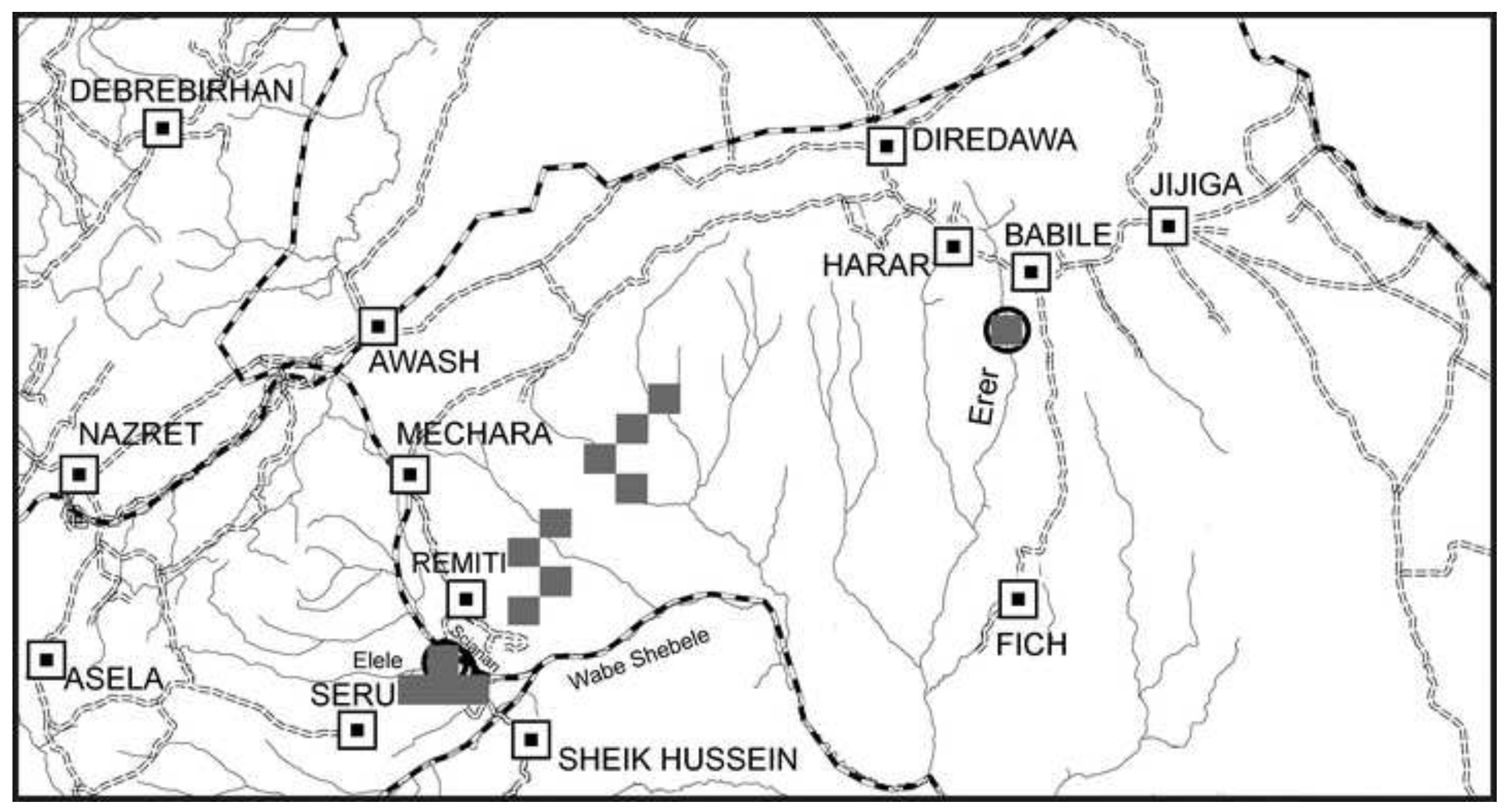




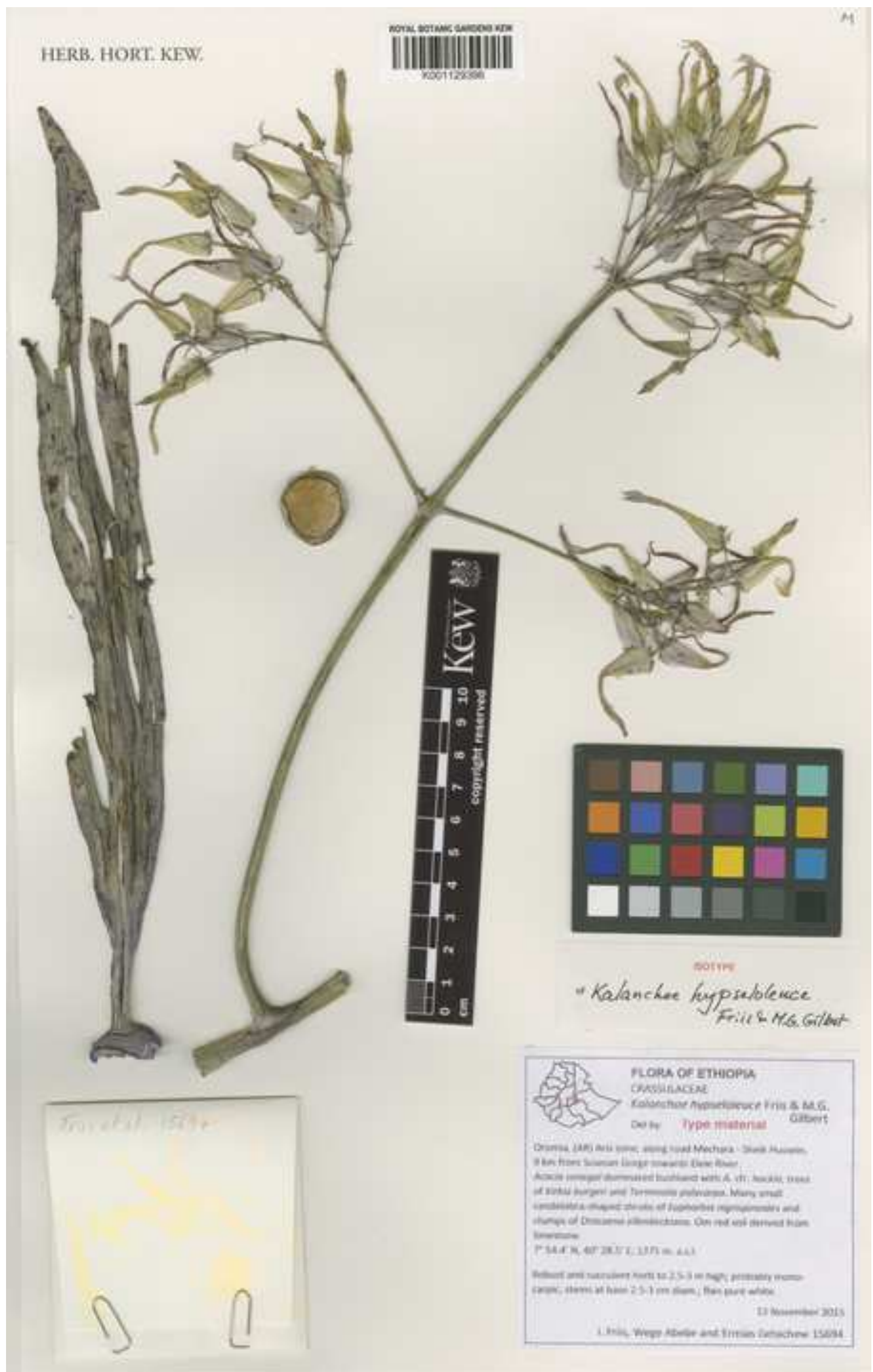


Table 1. Records (collected specimen, sight records or from the calculated climate envelope) of

Kalanchoe hypseloleuce used in the EOO and AOO calculations. Latitude and Longitude are given in decimal degrees.

\begin{tabular}{|c|c|c|c|c|c|}
\hline Record & Latitude & Longitude & $\begin{array}{l}\text { \# records } \\
\text { used }\end{array}$ & $\begin{array}{l}\text { EOO in } \\
\mathrm{km}^{2}\end{array}$ & $\begin{array}{l}\mathrm{AOO} \text { in } \\
\mathrm{km}^{2}\end{array}$ \\
\hline Specimen (Burger 3596) & 9.05 & 42.35 & \multirow{4}{*}{4} & \multirow{4}{*}{817} & \multirow{4}{*}{16} \\
\hline Sight record, Nov. 2015 & 7.9550 & 40.4377 & & & \\
\hline Specimen (Friis et al. 15694) & 7.9111 & 40.4806 & & & \\
\hline Sight record, Nov. 2015 & 7.9067 & 40.4750 & & & \\
\hline Calculated climate envelope & 7.8235 & 40.4820 & \multirow{12}{*}{16} & \multirow{12}{*}{7712} & \multirow{12}{*}{64} \\
\hline Calculated climate envelope & 7.8552 & 40.3906 & & & \\
\hline Calculated climate envelope & 7.9545 & 40.4343 & & & \\
\hline Calculated climate envelope & 8.2803 & 40.7283 & & & \\
\hline Calculated climate envelope & 8.4113 & 40.8037 & & & \\
\hline Calculated climate envelope & 8.6258 & 40.9626 & & & \\
\hline Calculated climate envelope & 8.7490 & 41.0500 & & & \\
\hline Calculated climate envelope & 8.7966 & 41.1334 & & & \\
\hline Calculated climate envelope & 9.0469 & 42.2972 & & & \\
\hline Calculated climate envelope & 8.5504 & 41.0023 & & & \\
\hline Calculated climate envelope & 8.2167 & 40.7958 & & & \\
\hline Calculated climate envelope & 7.8076 & 40.5018 & & & \\
\hline
\end{tabular}


Kalanchoe hypseloleuce (Crassulaceae), a new species from eastern Ethiopia, with notes on its habitats

Ib Friis ${ }^{1,2}$, Michael G. Gilbert ${ }^{2}$, Paulo van Breugel $^{3}$, Odile Weber ${ }^{2}$, Sebsebe Demissew $^{2,4}$

Summary: A new species of Kalanchoe, K. hypseloleuce Friis \& M.G. Gilbert, was found during field work in Ethiopia in 2015, and is established here. It is characterised by its tall stature (2 - 3 m), entire, sessile, lanceolate leaves and pure white flowers with abaxially minutely papillose corolla lobes (otherwise, the plant is glabrous). It is not obviously related to any previously known species, but an earlier, incomplete specimen has been cited as K. prittwitzii Engl. in literature. Kalanchoe hypseloleuce was collected on limestone in Acacia-Commiphora woodland and bushland at c. $1400 \mathrm{~m}$ a.s.l. It occurs in the southern part of the eastern Ethiopian escarpment in the Arsi and Eastern Harerghe zones of the Oromo Regional State. Kalanchoe hypseloleuce is documented with images and maps, its climate envelope has been modelled, and a conservation assessment made. With the current level of threat, this could be Vulnerable to Near Threatened (VU-NT). Given the threat from habitat degradation is not imminent, we recommend the species to be listed as Near Threatened (NT).

Key Words: Acacia-Commiphora bushland, conservation, Afromontane forest, limestone, monocarpic, taxonomy, transitional semi-evergreen bushland.

\footnotetext{
${ }^{1}$ Biosystematics, Natural History Museum of Denmark, University of Copenhagen, Sølvgade 83, DK-1305 Copenhagen K, Denmark. E-mail: ibf@snm.ku.dk

2 The Herbarium, Royal Botanic Gardens, Kew, Richmond, Surrey, TW9 3AE, UK.

${ }^{3}$ Department of Geosciences and Natural Resource Management, Forest, Landscape and Biomass, University of Copenhagen, Rolighedsvej 23, Frederiksberg C, DK-1958, Denmark.

${ }^{4}$ The National Herbarium, Department of Plant Biology and Biodiversity Management, Addis Ababa University, P.O. Box 3434, Addis Ababa, Ethiopia.

[OrcIDs - I. Friis: 0000-0002-2438-1528; M.G. Gilbert: 0000-0001-8451-6925; P. van Breugel: 0000-0001-9579-0831;

O. Weber: 0000-0002-0861-2752; Sebsebe Demissew: 0000-0002-0123-9596]
} 
On field trips in 2013, 2014 and 2015 Ib Friis, Odile Weber and Sebsebe Demissew studied the vegetation and flora of little known limestone areas along the Wabe Shebele River and its tributaries in the Arsi, W. Harerghe and Bale Zones of Oromia Regional State, Ethiopia. The main purposes of the studies were to analyse and map the previously unrecognised vegetation type transitional semi-evergreen bushland (Friis et al. 2010; Breugel et al. 2016) and, for a study of the narrow endemic Crotalaria trifoliolata Baker f. (Leguminosae), to explore the Dry evergreen Afromontane forest and grassland complex of the Kubayo Forest Reserve (Friis \& Weber 2014; Friis et al. 2016).

\section{The habitat}

In SE Ethiopia, the Wabe Shebele River and its major tributaries have cut deep and steep-sided gorges in a relatively level terrain with a substrate of limestone (Map $1 \& 2$; Mengesha Tefera et al. 1996). The bottoms of these gorges are at $800-1000 \mathrm{~m}$ a.s.l. In some places, they may have cut below the limestone to the crystalline basement complex with schists and granites. The surrounding, more level terrain varies between 1000 and $1400 \mathrm{~m}$ a.s.l. (our field observations 2013 - 2015; Google Earth 2016). The dominant vegetation in the steep gorges and on the surrounding, flatter areas is a dry form of Acacia-Commiphora woodland and bushland (Friis et al. 2010). Upwards, at c. $1400 \mathrm{~m}$ a.s.1., this vegetation intergrades with transitional semi-evergreen bushland (Breugel et al. 2016; Friis et al. 2016), and slightly higher, at c. $1500 \mathrm{~m}$ a.s.1., the transitional semi-evergreen bushland borders with dry, open forest of Juniperus procera Hochst. ex Endl. (Friis et al. 15646), part of the dry evergreen Afromontane forest and grassland complex (Friis et al. 2010). Common species in the Acacia-Commiphora woodland and bushland in the gorges $\mathrm{N}$ of Sheik Hussein (Map 2) are the deciduous shrubs or small trees Acacia condyloclada Chiov. (Friis et al. 15580), A. cf. hockii De Wild. (Friis et al. 15563), A. senegal (L.) Willd., Commiphora boranensis Vollesen (Friis et al. 15571), C. gileadensis (L.) C. Chr. (Friis et al. 15106), C. kataf(Forssk.) Engl. (Friis et al. 
15557), C. ogadensis Chiov. (Friis et al. 15569), C. serrulata Engl. (Friis et al. 15574), Ozoroa insignis Del. (Friis et al. 15628), and the semi-evergreen shrubs Rhus natalensis Krauss (Friis et al. 15624) and Grewia schweinfurthii Burret (Friis et al. 15659). Emergent trees or large shrubs are the deciduous or semi-deciduous Kirkia burgeri Stannard (Friis et al. 14104), Terminalia brownii Fresen. (Friis et al. 15255), T. polycarpa Engl. \& Diels (Friis et al. 15092), and, in places, extensive clumps of the evergreen Dracaena ellenbeckiana Engl. (Friis et al. 15109). Together with Rhus natalensis and Grewia schweinfurthii, the latter is an important component of the Transitional semi-evergreen bushland, in which also Combretum molle G. Don (Friis et al. 15577) and Barbeya oleoides Schweinf. (Friis et al. 15656) were prominent. The ground is covered by low shrubby species, mainly of Acanthaceae, including Ruellia discifolia Oliv. (Friis et al. 15666), with long, white hawk-moth pollinated flowers, labiates, and, in places, dense and almost pure stands of the small, candelabra-shaped shrub Euphorbia nigrispinoides M.G. Gilbert (Friis et al. 15242).

Our visits to the river gorges $\mathrm{N}$ of Sheik Hussein in 2013, 2014 and 2015 all took place during the autumn rains. We observed that the rainfall and the lushness of the vegetation varied very strikingly between nearby places and from year to year. In Dec. 2013, the rainfall was moderate, and many species were green. In Nov. 2014, the rainfall was abundant in both the highlands and lowlands south of the Wabe Shebele and the vegetation was lush, but hardly any rain had fallen north of the Wabe Shebele, where nearly all species were leafless. In Nov. 2015, the rainfall was moderate south of the Wabe Shebele, but heavy $\mathrm{N}$ of the river, where, consequently, the Acacia-Commiphora woodland and bushland was green and many species flowering.

\section{A new species of Kalanchoe in this habitat}

In Acacia-Commiphora woodland and bushland under the moist conditions prevailing north of the Wabe Shebele in 2015, we found a new species of Kalanchoe flowering abundantly. Its long, gleamingly white flowers were reminiscent of the long, white hawk-moth flowers of Ruellia 
discifolia flowering nearby. Populations of this species of Kalanchoe were observed in three localities along the new road between the gorges of the Wabe Shebele and the Scianan rivers (Map $1 \& 2$; for a map with more detail, based on our field observations and showing vegetation, rivers and roads where Wabe Shebele and Scianan meet, see Friis et al. 2016: 22, Fig. 1). One of the three populations was photographed and sampled as Friis et al. 15694 (Fig. 1) and duplicate material sent from the National Herbarium, Addis Ababa (ETH) to the Herbarium of the Royal Botanic Gardens, Kew (K), where it was further studied by I. Friis and M.G. Gilbert. The collection did not key out as any previously described species of the Flora of Ethiopia (Gilbert 1989), the Flora of Somalia (Thulin 1993) or the Flora of Tropical East Africa (Wickens 1987), and our material did not agree with any later described species of Kalanchoe from Eastern Africa, as recorded in IPNI (2016). No matching material of named species was found at ETH or at $\mathrm{K}$, apart from one much less complete specimen collected in Ethiopia in 1964, Burger 3596 (K), which agreed with our material in diameter and structure of the stem and in characters of inflorescence and flowers. This collection had previously been cited as K. prittwitzii Engl. (Gilbert 1989). The leaves of Burger 3596 were only fragmentarily preserved, but the leaf bases, without a distinct petiole, agreed with our collection. We have no doubt that Burger 3596 represents the same species as our plant and that this species is unnamed and undescribed.

On the label of Burger 3596, the locality was indicated as 'Slopes west of the Uadendeo Plateau. 9 4' N, 42²2' E, c. 1400 m'. Using Google Earth (2016), we were not able to find a locality with exactly these coordinates and altitude. Given that at Burger's time the determination of altitude with an altimeter was more reliable than the determination of geographical coordinates, we assume that we should give the information about altitude most weight. From other collections made by Burger we know that he repeatedly collected along the road from Babile (on the Harar Jijiga road) to Fich (Map 2). According to Google Earth (2016), the road from Babile to Fich crosses the Uadendeo Plateau in a N-S direction at altitudes constantly between c. 1500 and 1640 
$\mathrm{m}$, and nowhere it approaches the edges of the plateau. At c. $1400 \mathrm{~m}$ on the $\mathrm{W}$ slope of the plateau towards the Erer valley, a few $\mathrm{km} \mathrm{W}$ of the position indicated by Burger, we can see a number of tracks in the open bushland, leading down rather steep slopes to settlements at c. $1350 \mathrm{~m}$ near the Erer River, a tributary of the Wabe Shebele. Therefore we find it necessary to relocalise Burger 3596 to a position at the correct altitude on the slope at c. $9^{\circ} 03^{\prime} \mathrm{N}, 42^{\circ} 21^{\prime} \mathrm{E}$ (in Table 1 converted to decimal degrees).

Burger's label states 'Gravelly granitic soil' as the substrate. According to the geological map of Ethiopia (Mengesha Tefera et al. 1996), this substrate is found at the bottom of the Erer valley and at lower altitudes further west and nearer to Babile. The substrate on the W slope of the Uadendeo Plateau and at our localities in Arsi is Jurassic limestone of the Hamanley Formation (Mengesha Tefera et al. 1996), which is widely exposed in the Wabe Shebele drainage system. The distance in direct line between Burger's locality and our localities is c. $230 \mathrm{~km}$, but topographic and geological conditions are similar in both places. Friis et al. 15694 and Burger 3596 have been collected in open Acacia-Commiphora woodland and bushland bordering the Transitional semievergreen bushland (Map 1).

In a previous study (Friis et al. 2016) we found that Engler's description of Hans Ellenbeck's trip through this area (Engler 1906), contained relevant, previously unnoticed floristic information. However, Engler's account did not list any plant that can be identical with our new Kalanchoe. The area transversed by Ellenbeck has hardly been explored botanically since the beginning of the $20^{\text {th }}$ century, and there are very few or no roads (Map 2).

With only four locations, three of which are within close proximity of one another, detailed modelling of the distribution of the species was considered problematic. However, to get an idea of the potential range, we used the Bioclim model (Busby 1991; Nix 1986) to compute the climate envelope within which the species is predicted to occur. This was done with DIVA-GIS (2015), using the climatic data set Bioclim from WorldClim (Hijmans et al. 2005; http://www.diva- 
gis.org/climate). The model produced a row of small, discontinuous areas (squares) with high probability for presence. These squares were all in proximity of intermittent or permanent rivers (Map 2) and all within areas where Jurassic limestone is present at altitudes between c. 1200 and $1400 \mathrm{~m}$. There is a large gap between the predicted square at the easternmost known location (Burger 3596) and the next square of predicted suitable climate to the west. We cannot explain this gap, in which there are river valleys with suitable substrate and altitude; we assume that the interpolated climatic data are inadequate to allow better prediction in this poorly known area (Hijmans et al. 2005).

\section{Key to Ethiopian species of Kalanchoe}

The following key is based on the key in Flora of Ethiopia and Eritrea (Gilbert 1989) and the numbering of the species follows that of the Flora. The new species keys to lead 2 in the original key, where it does not fit the first couplet because of the minutely papillose corolla lobes, and it differs from the species of the second couplet, $K$. schimperiana, in calyx length (and leaf characteristics and habit). The key couplets in Gilbert (1989) are unaltered from lead 4, but the following couplets must be renumbered. The tall habit and sessile leaves of the new species can resemble those of $K$. lanceolata and $K$. laciniata, but it differs from these in being glabrous except for the corolla and by the entire leaves.

1. Corolla tube $3-12 \mathrm{~cm}$ long, lobes pure white.

- Corolla tube $0.7-3 \mathrm{~cm}$ long, lobes yellow, orange, red or pink, rarely if ever pure white. Go to lead 4, in Gilbert (1989: 19).

2. Plant glabrous throughout except for corolla; calyx up to $20 \mathrm{~mm}$ long. 3

- $\quad$ Plant hairy, at least on inflorescence; calyx 25 - $40 \mathrm{~mm}$ long. 1. K. schimperiana 
3. Stem branched and decumbent at base, plants perennial; leaf margin crenate or serrate; corolla externally glabrous. .4

-. Stem unbranched below inflorescence, strictly erect (plants presumably monocarpic, see 'Note' in this paper); leaf margin entire; corolla externally minutely glandular papillose, mainly on lobes.

K. hypseloleuce

4. Leaves sessile, glaucous, often marked with dark blotches; corolla-tube $(4.5-) 6-12 \mathrm{~cm}$ long.

2. K. marmorata

- $\quad$ Leaves petiolate, unmarked; corolla-tube $3-5 \mathrm{~cm}$ long.

3. K. quartiniana

Kalanchoe hypseloleuce Friis \& M.G. Gilbert, sp. nov. Type: Ethiopia, Oromia, Arsi, at road Mechara - Sheik Hussein, 9 km from Scianan Gorge towards Elele River, 1375 m a.s.1., 13. Nov. 2015, I. Friis, Wege Abebe \& Ermias Getachew 15694 (holotype ETH[098987]!; isotypes C[C10021858]!, K[K001129396]!).

Erect succulent herb with single stems, to c. $3 \mathrm{~m}$ high, unbranched below inflorescence (basal parts not collected); all parts except corolla glabrous. Stem $20-25 \mathrm{~mm}$ in diam, cylindrical, smooth, dull pale green; internodes much shorter than leaves. Leaves uniformly distributed along stem, sessile, opposite decussate, spreading, slightly reflexed with upturned tip; lamina uniformly dull pale green, narrowly lanceolate to elliptic, to $28.5 \times 3 \mathrm{~cm}$, slightly smaller towards base, gradually smaller towards inflorescence, with shallowly upturned sides so as to be uniformly curved (U-shaped) in cross section, base cuneate, not amplexicaul, but connected by \pm distinct interpetiolar lines, margins entire, apex acute, no venation apparent. Inflorescence terminal, broadly ovoid, to almost $1 \mathrm{~m}$ long with 5 or 6 pairs of pedunculate cymes; cymes with peduncle to $20 \mathrm{~cm}$, upper internodes 4 or 5 , progressively shorter, most flowers clustered apically in 3- or 4-branched dichasia; bracts leaf-like, to $10 \times 0.6 \mathrm{~cm}$, somewhat recurved, uppermost bracts almost linear, ca. $5 \mathrm{~mm}$ long; pedicel to 12 
$\mathrm{mm}$ long. Sepals 4, free, spreading, narrowly triangular-lanceolate, $6-6.5 \times 1.5-1.8 \mathrm{~mm}$, apex acute, no venation apparent. Corolla pure white, abaxially minutely glandular-papillate towards apex of tube and especially on the half of the lobes not covered by other lobes in bud; tube narrowly urceolate, 30 - $39 \mathrm{~mm}$ long, to c. $9 \mathrm{~mm}$ wide near base, c. $3 \mathrm{~mm}$ wide near apex, slightly keeled between sepals, base widening in late anthesis; lobes lanceolate, $8-10 \times 3-4 \mathrm{~mm}$, apex narrowly acuminate. Stamens included, in 2 whorls of 4 , upper whorl with filaments $0.5-1 \mathrm{~mm}$ long, lower whorl with subsessile anthers, whorls inserted $1 \mathrm{~mm}$ and $3 \mathrm{~mm}$ below apex of tube; anthers $0.8-$ $0.9 \times 0.5-0.6 \mathrm{~mm}$, narrowing towards the tip. Carpels 4, c. $12 \mathrm{~mm}$ long, with styles c. $9.5 \mathrm{~mm}$ long, stigma inconspicuous; each carpel with linear nectary at base, to $6 \mathrm{~mm}$ long, c. $0.3 \mathrm{~mm}$ wide; also with bluntly triangular gland-like structures, possibly nectaries, $0.7 \mathrm{~mm}$ long and wide, alternating with carpels. Seeds c. 20 per carpel (follicle); only immature follicles and seeds seen. Fig. 1, 2.

Note on colouring of cell contents: A number of epidermal cells of the sepals, particularly on the abaxial side, have strikingly dark cell contents, turning almost black when the sepals wither. When injured during dissection with scalpel or needle, the contents of most cells of the sepals turn black. The $7-9 \mu \mathrm{m}$ long glandular hairs on the corolla lobes and upper part of tube have darkened, but not black cell contents, particularly in the apical, glandular part. This dark cell contents prevented us from observing if the hairs are divided by cell walls.

RECOGNITION. The species is distinguished from all other African members of the genus by the combination of the tall erect habit, to $3 \mathrm{~m}$, glabrous except for the minutely glandular-papillate corolla lobes, the sessile, entire leaves, and pure white corollas with the tube $3-4 \mathrm{~cm}$ long. Kalanchoe prittwitzii is the species most likely to be confused with $K$. hypseloleuce, because of its glabrous stems and leaves, fairly large stature and only slightly smaller flowers. However, it is very easily separated by the petiolate, broader, crenate to dentate margined leaves, as opposed to the 
sessile, narrower, entire margined leaves of $K$. hypseloleuce. It also differs by the smaller, entirely glabrous, mainly yellow, corolla with the tube $13-28 \mathrm{~mm}$ long, as opposed to the larger, partly papillate, pure white, corolla, tube $30-39 \mathrm{~mm}$ long, of $K$. hypseloleuce. Other African species of comparable habit (e.g. K. lanceolata (Forssk.) Pers.) have crenate to dentate margined leaves and smaller, yellow, orange or red corollas less than $3 \mathrm{~cm}$ long. Other species with similarly long, white, corollas (e.g. K. schimperiana A. Rich.) are perennials with stems decumbent at the base and with petiolate leaves with crenate to dentate margins.

DISTRIBUTION. Africa: Ethiopia, Oromia Regional State (see above and Map $1 \&$ 2).

SPECIMENS EXAMINED. ETHIOPIA. Oromia Regional State, [East Harerghe Zone], slopes west of Uadendeo Plateau. $9^{\circ} 4^{\prime} \mathrm{N}, 42^{\circ} 22^{\prime} \mathrm{E}$ [corrected to c. $9^{\circ} 03^{\prime} \mathrm{N}, 42^{\circ} 21^{\prime}$ E to agree with slope and altitude], c. 1400 m a.s.1. 22 Nov.1964, Burger 3596 (K!, EA), Arsi Zone, at the road between Mechara and Sheik Hussein, 9 km from Scianan Gorge towards Elele River. $7^{\circ} 54^{\prime} 40^{\prime \prime} \mathrm{N}$, 40² 28' 50" E, 1375 m a.s.1., 13 Nov.2015, I. Friis, Wege Abebe \& Ermias Getachew 15694 (ETH[098987]!, holotype, C[C10021858]!, K[K001129396]!, isotypes).

HABITAT. Acacia-Commiphora woodland and bushland on fine-grained red soil derived from Jurassic limestone and with floristic elements of the Transitional semi-evergreen bushland at higher elevation (see introduction); alt. 1350 - c. 1400 m. See section 'The Habitat', Map 1 and Fig. 1.

CONSERVATION STATUS. The available data allows us to assess the species under criterion B of the IUCN Red List system. The extent of occurrence (EOO) based on our observations (specimens and sight records, listed in Table 1) is $817 \mathrm{~km}^{2}$, which is far below the threshold of 5000 $\mathrm{km}^{2}$ for Endangered (EN). The corresponding area of occupancy (AOO) is $16 \mathrm{~km}^{2}$, with a cell width 
of $2 \mathrm{~km}$ as recommended by IUCN (2012); this is also below the threshold for EN (<500 km²). Both calculations were carried out with the online conservation assessment tool GeoCAT (Bachman et al. 2011). Furthermore, we ran a climate envelope model (see last paragraph of 'A new species of Kalanchoe in this habitat') to predict areas of suitable climatic conditions for Kalanchoe hypseloleuce (Map 2). From the resulting map, we selected additional coordinates (listed in Table 1) to run the EOO and AOO calculations again. The new EOO is $7712 \mathrm{~km}^{2}$ and the AOO is $64 \mathrm{~km}^{2}$ (with the default cell width of $2 \mathrm{~km}$ ). These values are below the thresholds for Vulnerable (VU) and Endangered (EN) respectively. The AOO requires a minimum sample size of 125 locations scattered at intervals of $2 \mathrm{~km}$ or more in order to get a result above the threshold for EN $\left(500 \mathrm{~km}^{2}\right)$. We therefore deem the EOO calculation to be more reliable for the assessment.

Observations on the western-most location (E Arsi): We observed Kalanchoe hypseloleuce only after the abundant rains in November, 2015; not during our visit in the dry November of 2014. We saw the species in three different sites, at 3.6 and $4.5 \mathrm{~km}$ distance of each other. In all three sites, it occurred in groups of two to four individuals, all flowering approximately at the same time. We assume that the species is monocarpic (see discussion in 'Notes') and germinates under suitable climatic conditions from seeds in the soil seed bank. We assume it does not benefit from moderate disturbance since there were other sites of more disturbed open bushland north-east of the Scianan River and the village of Remiti (Map 2) where we would have expected the species to occur, but we didn't see it.

At present, there is no formal protection of the location in E Arsi, nor is there any significant human influence. Large areas around the location were sparsely inhabited or not at all. The vegetation seemed uniform on the flat limestone-areas between the gorges of the Elele and the Scianan Rivers, a distance of c. $20 \mathrm{~km}$. No village could be seen from the road for a distance of approximately $30 \mathrm{~km}$. (The village Seru in Arsi is c. $40 \mathrm{~km}$ to the SW, at $1650 \mathrm{~m}$ a.s.1., Sheik 
Hussein in Bale is c. $30 \mathrm{~km}$ to the S, at $1350 \mathrm{~m}$ a.s.l., and Remiti, also called Bui, in W Harerghe is c. $20 \mathrm{~km}$ to the $\mathrm{N}$, at $1500 \mathrm{~m}$ a.s.1.; see Map 2).

In E Arsi, nomadic Oromos do use the vegetation for grazing camels. We saw only a few camels $\mathrm{N}$ of the Elele River, mostly a few animals left to graze by themselves, and flocks of sheep and cows only between the Elele and Wabe Shebele Rivers. We did not meet any herdsmen along this stretch of road between Elele and Scianan. We conclude that currently, the grazing in the area doesn't present a threat to the flora.

Observations on the eastern-most location (E Harerghe): The situation is different at the location in E Harerghe, where Burger 3569 was collected, nearly $250 \mathrm{~km}$ east of our observed locations in the west. That location now falls within the formally protected Babile Elephant Sanctuary, but protection of this conservation area is inadequate. Vegetation and wildlife in this region are declining (Mesfin Seifu \& Fekadu Beyene 2014), and plant and animal species are under pressure.

Observations on the modelled intermediate locations: We assume that the species occurs in the locations predicted by the climate envelope model between the observed locations in E Arsi and the population in E Harerghe (Map 2, Table 1). There is an unexplained gap of nearly $150 \mathrm{~km}$ between the eastern-most population in E Harerghe and the model prediction. From what we can see on Google Earth (2016), some of the predicted locations are intensely farmed and comparatively densely populated, although not accessible by road. Others look almost completely uninhabited, like the observed locations in E Arsi.

We have not observed a decline in the quality or extent of the habitat in E Arsi, but we suspect the situation to change in the near future as a result of the growing human population and new roads. In the areas we have visited in W Harerghe, north of E Arsi, there is a considerable amount of deterioration from human activity (cutting of trees), cattle grazing, soil erosion and encroachment of invasive species. Solanum dennekense Damme (indigenous to Ethiopia and 
Somalia) and Calotropsis procera (Aiton) Dryand (widespread in dry tropical Asia as well) are two woody species that are aggressively replacing other woody plants, in particular where the vegetation is overgrazed. We suspect this will be the situation elsewhere within the predicted range of Kalanchoe hypseloleuce and may be so also in E Arsi in the future.

Climate change may constitute a risk given the species relies on rain fall to initiate sprouting from seeds in the seed bank.

Kalanchoe hypseloleuce doesn't fully meet the conditions to be evaluated as threatened under B1 since it only meets one of the three sub-criteria (B1biii - inferred decline in the quality of the habitat) but could be Vulnerable to Near Threatened (VU-NT) (IUCN 2016: 20). We don't think the habitat is severely fragmented or that the species occurs in fewer than 11 locations. However, we are uncertain about potential extreme fluctuations in the number of mature individuals. If the species is monocarpic, the populations alternate between mature individuals and individuals surviving as seeds in the seed bank. We have not observed successive maxima and minima in the number of mature individuals but it is possible that the number of mature individuals fluctuates a lot with the rather erratic rainfall in the region. Given the threat from habitat degradation is not imminent, we recommend the species to be listed as NT under B1biii (suspected decline in the quality of the habitat in the future), pending further research.

PHENOLOGY. The two known gatherings both flowered in November to December, which is during the autumn rainy season.

ETYMOLOGY. Our new epithet, hypseloleuce, is a compound of two Greek adjectives. The first,

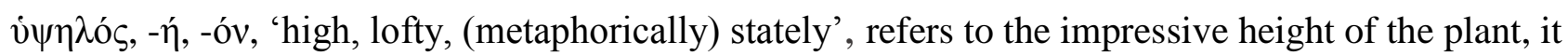

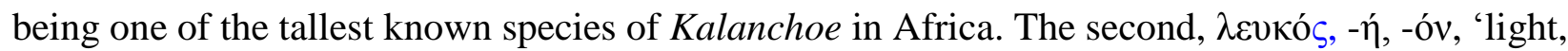
bright, (of colour) white', refers to the pure white flowers. The connecting vowel $-\mathrm{O}-$ is in 
agreement with Rec. 60G(a2) of the Code (McNeil et al. 2012). The generic name, Kalanchoe Adans. (1763), is said to be an adaptation of a Chinese name for a species in the genus (Harvey 1862) or derived from a Hindi word 'kalanka', meaning 'rust' or 'spot' (Quattrocchi 2000). In botanical literature, Kalanchoe is treated as feminine and, in agreement with Art, 23.5 of the Code, the feminine form of the terminal adjective is used.

VERNACULAR NAME. None recorded.

USES. None recorded.

NOTES. Relationships amongst the mainland African species of Kalanchoe have never been investigated in any detail. Gehrig et al. (2001) presented a molecular phylogeny of the genus as a whole but this concentrated primarily on the many Madagascan members of the genus and included only a small selection of the mainland species. The analysis showed that these formed a monophyletic group apparently derived from within one of the three main Madagascan groups recognised but it lacked any useful resolution within this group. It does however show that we should look for relationships of the new species from amongst the species found on mainland Africa.

The oldest collection of the new species, Burger 3596, was originally cited as the only record of K. prittwitzii for the Flora of Ethiopia and Eritrea (Gilbert 1989). This was based on the robust stem, apparent lack of any indumentum and the length of the corolla. The material was too incomplete to show the habit and leaf shape and the distinctive minute glandular papillae on the corolla were missed. The much more complete second collection has shown that that determination was mistaken but it should be noted that $K$. prittwitzii must be retained in the Ethiopian Flora as 
there has been a subsequent genuine collection of this species from within the Flora area, Friis et al. 8738 from $20 \mathrm{~km} \mathrm{NW}$ of Moyale.

The diagnostic features of $K$. hypseloleuce are the tall, solitary stems, the total lack of indumentum except for the corolla, the distinctive sessile, narrow, entire leaves and the pure white flowers with distinctive minutely glandular-papillate lobes. The small and scattered clumps of tall and stiffly erect stems look extremely similar in habit and distribution of individuals in small, clustered populations to those of known monocarpic species such as $K$. densiflora Rolfe and $K$. lanceolata (Forssk.) Pers. From our field studies of characteristic populations in E Arsi and from comparisons with other African species of Kalanchoe of known life span we believe $K$. hypseloleuce to be monocarpic and to grow opportunistically from seeds in the soil seed bank. The indumentum of the corolla needs good magnification to see but provides a good diagnostic character. In K. hypseloleuce, the indumentum is of densely packed, minute, blunt papillae distributed primarily on the outside of the corolla lobes and only spreading a short way along the corolla tube, which is mostly glabrous. The only species seen with an essentially similar corolla indumentum is $K$. usambarensis Engl. \& Raym.-Ham., which also has minutely papillate corolla lobes and glabrous corolla tube but the two species differ in virtually all other characters, as $K$. usambarensis is a small, clump-forming perennial with petiolate leaves and small, red corollas. The vast majority of the East African species have entirely glabrous corollas. Two species, $K$. schimperiana and K. citrina Schweinf. have densely pubescent, almost tomentose, corolla tubes with the corolla lobes more sparsely hairy, quite different from our new species in both the type of hairs and the pattern of their distribution. Hairy corollas also occur in K. densiflora and $K$. lanceolata but these are uniformly very sparsely glandular hairy and again quite different.

There is a good correlation amongst the African species between corolla length and colour, with all white-flowered species having corolla tubes more than $30 \mathrm{~mm}$ long, probably hawk-moth pollinated, whilst all the yellow, orange, pink and red flowered species have corolla tubes up to 28 
mm long. The other white-flowered species, $K$. aubrevillei Cuf., K. marmorata Bak., K. peteri Werderm., K. quartiniana A. Rich., and K. schimperiana A. Rich., are all clump-forming perennials with distinctly petiolate, crenate or dentate leaves and do not seem to be closely related.

Other apparently monocarpic species most similar in habit, such as $K$. densiflora Rolfe, $K$. lanceolata (Forssk.) Pers., K. mitejea Leblanc \& Raym.-Ham. and K. nyikae Engl., all differ by the smaller yellow corollas, tubes to $22 \mathrm{~mm}$ long which are entirely glabrous or uniformly very sparsely glandular hairy. Kalanchoe mitejea and K. nyikae approach K. hypseloleuce in overall size and in having entire leaves but the leaves of both species are much broader and are very distinctly petiolate. Other species with entire leaves are all clump forming perennials much smaller in stature.

\section{ACNOWLEDGEMENTS}

We are grateful to the Carlsberg Foundation, Copenhagen, for continued financial support of our studies of Ethiopian flora and vegetation. The Bentham-Moxon Trust, RBG Kew, supported Odile Weber's participation in the field-work in 2013. The specimens from the field trips in 2013-2015 were identified by us at the herbarium of the Royal Botanic Gardens, Kew, where we also received help with their handling. Ib Friis, Odile Weber and Sebsebe Demissew want to thank their travel companions on the field trips: Wege Abebe, Addis Ababa University (on all trips, also very helpful with the handling of the collections at ETH), Abubaker Adem (our guide from Bale), Adem Beyane (our guide from Harerghe), and Ermias Getachew, driver at the Faculty of Science, Addis Ababa University (on all trips). They have been excellent helpers and good company. Professor Asfawossen Asrat, Addis Ababa University, kindly commented on the geology of the area, and Quentin Luke, Nairobi, found a duplicate of Burger 3596 for us at the East African Herbarium (EA). Finally, we are grateful to Steve Bachman, Kew, for help with GeoCAT and Victoria G. Friis, Copenhagen, for having produced the drawings for Fig. 2, as well as for her help with dissections and her observant analyses of floral details. 


\section{References}

Bachman, S., Moat, J., Hill, A. W., de la Torre, J. \& Scott, B. (2011). Supporting Red List threat assessments with GeoCAT: geospatial conservation assessment tool. - In: V. Smith \& L. Penev (eds), e-Infrastructures for data publishing in biodiversity science. ZooKeys 150: 117 - 126, and GeoCAT. Geospatial Conservation Assessment Tool. [On line]. http://geocat.kew.org/ (accessed 14 May, 2016).

Breugel, P. von, Friis, I. \& Sebsebe Demissew (2016). The transitional semi-evergreen bushland in Ethiopia: characterization and mapping of its distribution using predictive modelling. Appl. Veg. Sci. 19(2): $355-367$.

Busby, J. (1991). BIOCLIM - a bioclimate analysis and prediction system. In: C. Margules \& M. Austin (eds), Nature Conservation: Cost Effective Biological Surveys and Data Analyses, pp. 64 68. CSIRO, Melbourne.

DIVA-GIS (2015). DIVA-GIS 7.5, and climate data [On line]. http://www.diva-gis.org/ and http://www.diva-gis.org/climate (both accessed 18 August, 2015).

Engler, A. (1906). Über die Vegetationsverhältnisse von Harar und des Gallahochlandes auf Grund der Expedition von Freiherrn von Erlanger und Hrn. Oscar Neumann. Sitzungsber. königl. Preuss. Akad. Wiss. Berlin 40(2): 726 - 747.

Friis, I., Sebsebe Demissew \& Breugel, P. van (2010). Atlas of the potential natural vegetation of Ethiopia. Biol. Skr. 58: 1 - 307. 
Friis, I. \& Weber, O. (2014). Crotalaria trifoliolata (Leguminosae: Papilionoideae), a previously incompletely known Ethiopian endemic rediscovered after 120 years. Kew Bull. 69: 9536, pp. 1 - 9. DOI: $10.1007 / \mathrm{S} 12225-014-9536-7$.

Friis, I., Weber, O., van Breugel, P. \& Sebsebe Demissew (2016). An endangered Ethiopian endemic, Crotalaria trifoliolata (Leguminosae: Papilionoideae), and its little-known habitat - Acta Univ. Upsal. Symb. Bot. Upsal. 38: 19 - 39.

Gehrig, H., Gaußmann, O., Marx, H., Schwarzott, D. \& Kluge, M. (2001). Molecular phylogeny of the genus Kalanchoe (Crassulaceae) inferred from nucleotide sequences of the ITS-1 and ITS-2 regions. Plant. Sci. 160: $827-835$.

Gilbert, M.G. (1989). Crassulaceae. In: I. Hedberg \& S. Edwards (eds), Flora of Ethiopia, vol. 3: 5 - 26. Addis Ababa, Asmara and Uppsala.

Google Earth. (2016). Google Earth. Vers. 7.1.5.1557 [On line]. (Accessed 15 May, 2016).

Harvey, W. H. (1862). VIII. Kalanchoe Adans. In: W.H. Harvey \& O.W. Sonder (eds), Flora Capensis, vol. 2, pp. 378 - 380. Hodges, Smith \& Co., Dublin.

Hijmans, R. J., Cameron, S. E., Parra, J. L., Jones, P. G. \& Jarvis, A. (2005). Very high resolution interpolated climate surfaces for global land areas. Internat. J. Climatology 25: $1965-1978$.

IPNI (2016). International Plant Names Index. [On line]. http://www.ipni.org/ (accessed 15 May 2016). 
IUCN. (2012). IUCN Red List Categories and Criteria. Vers. 3.1. Second ed. Gland \& Cambridge. the EOOs and AOOs fall within B1 and B2 range thresholds for Vulnerable (VU) and Endangered $(\mathrm{EN})$

— (2016). IUCN Standards and Petitions Subcommittee. 2016. Guidelines for Using the IUCN Red List Categories and Criteria. Version 12 (February 2016). Prepared by the Standards and Petitions Subcommittee. [On line]. http://www.iucnredlist.org/documents /RedListGuidelines.pdf (accessed 30 September 2016).

McNeill, J., Barrie, F.R., Buck, W. R., Demoulin, V., Greuter, W., Hawksworth, D.L., Herendeen, P.S., Knapp, S., Marhold, K., Prado, J., Prud'homme van Reine, W.F., Smith, G. F., Wiersema, J.H. \& Turland, N.J. (2012). International Code of Nomenclature for algae, fungi, and plants (Melbourne Code). Regnum Veg. 154.

Mengesha Tefera, Tadiwos Chernet \& Workineh Haro (1996). Geological Map of Ethiopia. $2^{\text {nd }}$ Edtion. Ministry of Mines, Geological Survey of Ethiopia, GSE, Addis Ababa. http://extra.geus.info/cet/ethiopia/Ethiopia_Map.pdf (Accessed 15 May, 2016)

Mesfin Seifu \& Fekadu Beyene (2014). Local livelihoods and institutions in managing wildlife ecosystems: The case of Babile Elephant Sanctuary in Ethiopia. Journal for Nature Conservation 22(6): $559-569$. 
Nix, H. A. (1986). A biogeographic analysis of the Australian elapid snakes. In: R. Longmore (ed.), Atlas of Elapid Snakes of Australia. Australian Flora and Fauna Series, No. 7, pp. 4 - 15. Australian Government Publishing Services, Canberra.

Quattrocchi, U. (2000). CRC World Dictionary of Plant Names. Vol. 2, D-L. CRC Press, London, New York, Washington DC.

Thulin, M. (1993). Crassulaceae. In: M. Thulin (ed.), Flora of Somalia, Vol. 1, pp. 87 - 93. Royal Botanic Gardens, Kew.

Wickens, G.E. 1987. Crassulaceae. In: R.M. Polhill (ed.), Flora of Tropical East Africa. A.A. Balkema, Rotterdam. 
Map 1. Observed distribution of Kalanchoe hypseloleuce. The red bird-eye dots, imposed on a modified vegetation map of Friis et al. (2010), indicate the known populations. The vegetation types are: AA, Afroalpine belt; ACB, Acacia-Commiphora woodland and bushland proper; ACB/RV, Acacia wooded grassland in the Rift Valley; DAF, Dry evergreen Afromontane forest and grassland complex; EB, Ericaceous belt; FLV/OW, Freshwater lakes - open water vegetation; FLV/MFS, Freshwater marshes and swamps, floodplains and lake shore vegetation; SLV, Salt lakes and Salt pans. A layer with the signature for Transitional semi-evergreen bushland (TSEB), as modelled for Breugel et al. (2016: Fig. 4a), has been added to the signatures for ACB and ACB/RV. The dark lines indicate the floristic boundaries used in the Flora of Ethiopia and Eritrea (Gilbert 1989); these boundaries are also shown on the inset map of Ethiopia, where the abbreviations are: AF, Afar region below 1000 m contour; AR, Arsi region; BA, Bale region; HA, Harerghe region; SU, Shewa region above $1000 \mathrm{~m}$ contour).

Map 2. Modelled distribution of Kalanchoe hypseloleuce. Grey squares: modelled climate envelope (see text). The areas of the squares were enlarged by $50 \%$ for clarity. Circles: known populations of the species (as in Map 1). White squares with black centre: major towns and small towns and villages mentioned in the text. Thick stippled lines: borders between floristic regions (as in Map 1). Thin unbroken lines: perennial rivers and streams. Double stippled lines: motorable roads. Roads as in Friis et al. (2010), corrected by field observations and GPS-readings from our work in 2013, 2014 and 2015. 
Fig. 1. Kalanchoe hypseloleuce. A flowering specimens in E Arsi zone, Ethiopia; in the background fruiting Acacia senegal and flowering and fruiting Grewia schweinfurthii; in the foreground flowering Rhus natalensis. B detail of inflorescence. PHOTOS: IB FRIIS.

Fig. 2. Kalanchoe hypseloleuce. A flower; B part of flower at late anthesis, when basal part of corolla tube swells and sepals fall individually (one sepal has fallen); $\mathbf{C}$ abaxial side of sepal; $\mathbf{D}$ adaxial side of sepal; $\mathbf{E}$ adaxial side of dried sepal at late anthesis; $\mathbf{F}$ dissection of corolla, showing androecium and gynoecium; $\mathbf{G}$ abaxial side of corolla lobe with short glandular hairs on the half not covered by other lobes in bud; $\mathbf{H}$ glandular hair; $\mathbf{K}$ bract supporting main branches of the inflorescence; L leaf from middle part of stem, one of a pair. All drawn from Friis et al. 15694 and I. Friis' photographs. Scale bars A, B \& F \& K 2 cm; C, D, E 3 mm; G 5 mm; H $5 \mu \mathrm{m}$; L 5 cm. DRAWN BY VICTORIA G. FRIIS. 